\title{
Embryonic growth and the evolution of the mammalian Y chromosome. II. Suppression of selfish Y-linked growth factors may explain escape from $X$-inactivation and rapid evolution of Sry
}

\author{
LAURENCE D. HURST \\ Department of Genetics, Downing Street, Cambridge CB2 3EH, U.K.
}

\begin{abstract}
The mammalian Y chromosome may be an attractor for selfish growth factors. A suppressor of the selfish growth effects would be expected to spread were it to have an appropriate parent-specific expression rule. A suppressor could act by boosting the resource demands of competing female embryos. This possibility may explain incidences of the escape from $X$-inactivation and provides a rationale for why these genes typically have Y-linked homologues. Alternatively, a suppressor could act to decrease the resource demands of males with the selfish Y. This possibility is supported by the finding that the size of male, but not female, human infants is negatively correlated to the number of X chromosomes. A protracted arms race between a selfish gene and its suppressor may ensue. Both the variation in copy number of Zfy and the unusually fast sequence evolution of Sry may be explained by such an arms race. As required by the model, human Sry is known to have an $\mathrm{X}$-linked suppressor. Preliminary evidence suggests that, as predicted, rapid sequence evolution of Sry may be correlated with female promiscuity. The case for fast sequence evolution as the product of maternal/foetal conflict is strengthened by consideration of the rapid evolution of placental lactogens in both ruminants and rodents.
\end{abstract}

Keywords: genomic imprinting, selfish genes, Sry, X-inactivation avoidance, Y chromosome.

\section{Introduction}

In the previous paper (Hurst, 1994, this issue) I proposed that the $Y$ chromosome of mammals may be expected to harbour selfish growth factors. The spread of a selfish neo-imprinted gene on the $\mathrm{Y}$ (as with many other selfish genes) is expected to provide the conditions required for the spread of a suppressor of the gene. The sex ratio effect associated with selfish Y-linked genes and the skewed resource allocation will both contribute to selection favouring the spread of a suppressor. For a suppressor to spread it must have an appropriate genomic location (unlinked) and expression pattern. A suppressor on the selfish $\mathrm{Y}$, for instance, could not invade. In this paper I consider two forms of suppressive response to a selfish Y. First, a gene may act to boost female growth demands. Second, a gene may inhibit male demands. I shall argue that the former possibility may explain escape from $\mathrm{X}$-inactivation whilst the latter may explain copy number variation of Zfy and rapid evolution of Sry.

\section{Selfish Y-linked growth promoters may create the conditions for females to boost their resource demands: an alternative rationale for those genes that escape $X$ - inactivation}

One means to control the excess resource allocation to males would be for $\mathrm{X}$-linked genes to act in female foetuses so as to match the resource demands of their $X Y$ sibs (or half sibs). If the demands are equal, then the resource allocation should also be equalized. Imagine that the start condition was one in which in a male the $\mathrm{X}$-linked gene was expressed but Y-linked 
ones were shut down (or not present). In females, one $X$ would be inactive (in somatic cells of female eutherian mammals one $\mathrm{X}$ is inactive). The growth demands of the male and female foetuses would be the same. Now imagine that the Y-linked sequence mutates (or a copy of the $\mathrm{X}$-linked gene is newly transferred onto the $Y$ ) so as to be able to exercise some growth effect. Both the $\mathrm{X}$ and the $\mathrm{Y}$ sequence would hence be acting as growth factors. This Y-linked mutant gene should now spread as a selfish gene, possibly to the point where all Ys were selfish. A mutant X-linked gene, homologous to the selfish $\mathrm{Y}$ gene that escaped inactivation, when in a female would be an efficient counter to the selfish effects of the Y. This would allow females to express two doses of this growth factor and so match the resource demands of the males. Suppression of a selfish Y may hence explain the avoidance of $\mathrm{X}$-inactivation of genes with Y-linked homologues.

In humans a few genes avoid $\mathrm{X}$-inactivation and hence are expressed in two doses. Most of the genes that avoid inactivation have a Y-linked homologue. The human $\mathrm{X}$-linked genes known to have Y-linked homologous sequences and that probably avoid inactivation presently number at least nine: $A M G X$, KALIG1, GS1, ANT3, XG, MIC2, STSX, RPS4X, ZFX (Goodfellow \& Tippett, 1981; Migeon et al., 1982; Goodfellow et al., 1984; Schneider-Gädicke et al., 1989; Fisher et al., 1990; Salido et al., 1992; Yen et al., 1992; Slim et al., 1993; Schiebel et al., 1993; reviewed in Ballabio \& Willard, 1992)(Fig. 1). Classical theories of this avoidance of $\mathrm{X}$-inactivation suppose that these genes need to be expressed in high doses in a relatively short time span: one X-linked copy in both males and females cannot supply adequate titres of the required gene products. This theory has one major weakness, namely, it does not necessarily predict the evolution of the avoidance of $\mathrm{X}$-inactivation. Duplication of the $\mathrm{X}$-linked gene sequence would be an alternative route to high dosage (and would avoid, in the long term, all the problems of having active genes on the Y). Surely, this duplication would be the easier route to take? In contrast to the classical theory in which the Y-linkage of the $\mathrm{X}$ homologue is not necessary (and the same net result could equally well be achieved by the maintenance of $\mathrm{X}$-inactivation and duplication of the $\mathrm{X}$-linked sequence), the conflict-based view envisages the Y-linkage of the gene as being integral to the evolutionary process.

Both classical and conflict-based theories make similar sets of predictions and face similar problems. Both theories predict that the $\mathrm{X}$-linked sequences that avoid inactivation should have Y-linked homologues. This appears generally to be the case (SchneiderGädicke et al., 1989; Fisher et al., 1990 and above references) (Fig. 1). There is, however, a number of contradictory facts (problematic to both hypotheses). $U B E 1 X$ escapes inactivation on the human $\mathrm{X}$ but Ubelyl sequences have yet to be found on the human Y (see Disteche et al., 1992 for references). Human STSY is inactive (Migeon et al., 1982) while the $\mathrm{X}$-linked gene partially avoids inactivation (Migeon et al., 1982). In contrast, murine Stsy is active but in this instance the X-linked Stsx (murine Sts is in fact pseudoautosomal) does not escape $\mathrm{X}$-inactivation (Jones et al., 1989; but see Keitges \& Gartler, 1986). Human KALIG1's Y-linked sequence is a pseudogene.

The conflict-based theory predicts that the homologous $\mathrm{X}$ and $\mathrm{Y}$ sequences should be foetally expressed growth factors. However, if embryonic growth is rapid and hence requires high levels of gene expression in short time frames, classical theory could make the same prediction. Available evidence supports the view that at least some of the $\mathrm{X}$-inactivation escapees are growth-related factors. Human $\mathrm{XO}$ foetuses are typically growth-retarded but murine $\mathrm{XO}$ foetuses are not. That three human escapees (RPS4X, ZFX, $U B E 1 X)$ are inactivated in mice leads to the suggestion that the removal of these genes is responsible for the severe growth retardation of human $\mathrm{XO}$ offspring (Ashworth et al., 1991). Ogata \& Matsuo (1993) review the data on disruption (including deletion) of the noninactivated genes and conclude that the data are consistent with at least some of these genes acting as growth factors as the above offspring are, as predicted, growth-retarded. No effect on human adult height of genes in $\mathrm{Xq}$ could be detected (Ogata \& Matsuo, 1993). Only one gene (RSP4X) avoiding Xinactivation is found on Xq. Fisher et al. (1990) argue, from deletion analysis, that RSP4Y could be a good candidate for many of the effects associated with Turner's syndrome.

Indirect suggestive evidence that the genes may be growth factors can also be found as several of the genes (or their homologues) have been implicated in slow development if under-expressed, or are associated with carcinoma if over-expressed. STS deficiency, for instance, is associated with late parturition in humans (Fraser et al., 1987) and, like GS1 (Yen et al., 1992), is known to be expressed in placental tissues as might be expected of genes involved in maternal/foetal transplacental interactions. Over-expression of the $M I C 2$ product (E2) is associated with Ewing's sarcoma (Fellinger et al., 1992), while $Z F Y$ expression is observed in human prostate adenocarcinoma (Tricoli \& Bracken, 1993). Expression of Amg is observed in human ameloblastoma tumours (Snead et al., 1992). Mutation/deletion of KALIG1 is associated with reduced growth of the gonads (Kallmann's syndrome) 


\section{Human $\mathrm{X}$ and $\mathrm{Y}$}

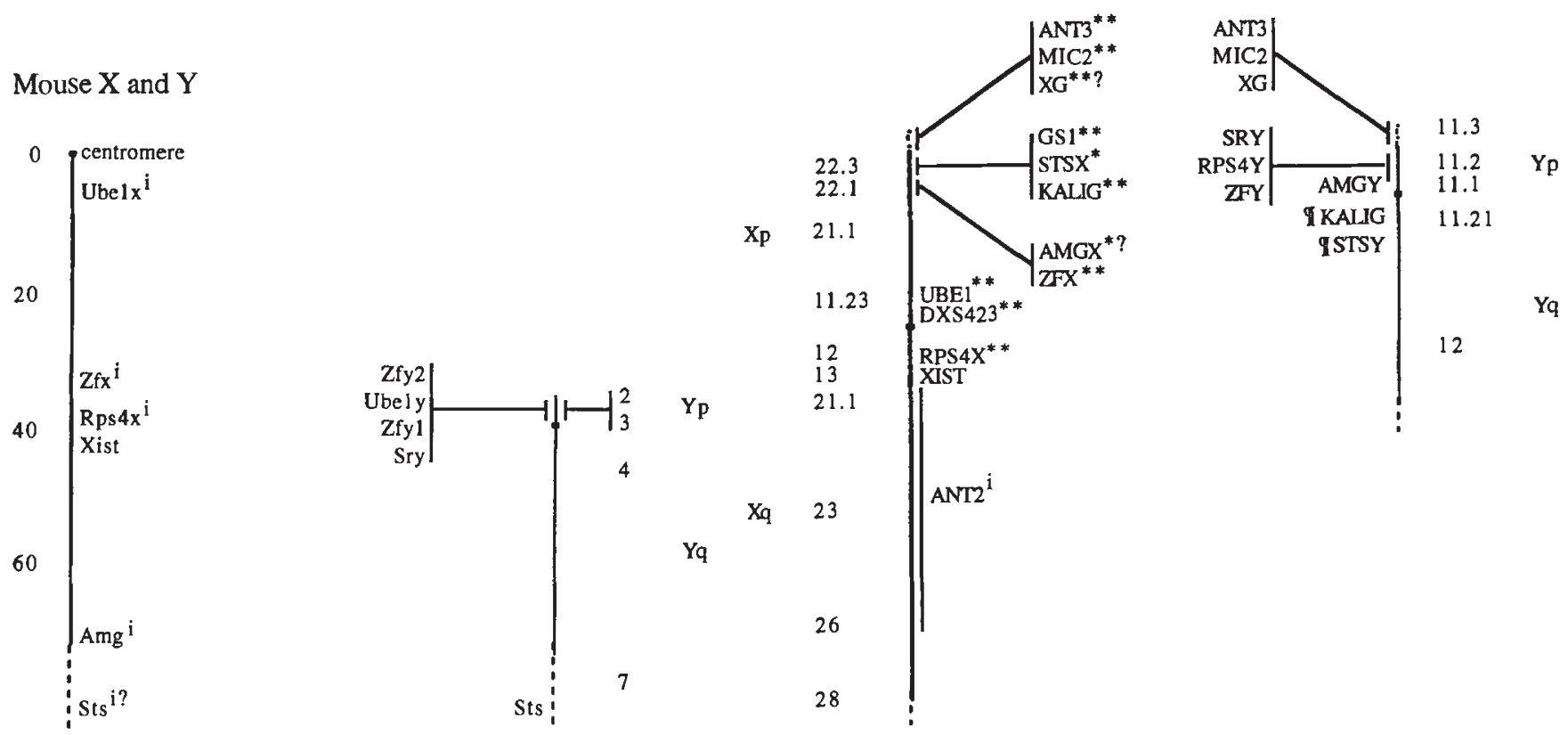

Fig. 1 Maps of mouse and human sex chromosomes including X-inactivation status. On one side of each chromosome map positions are provided, whilst on the other gene abbreviations are given. Dotted lines indicate the pseudoautosomal region. The human pseudoautosomal boundary probably runs through XG with three exons of XG being pseudoautosomal and the remaining seven X-linked. The mouse $A m g$ locus is just next to the pseudoautosomal boundary on the nonrecombining part of the $\mathrm{X}$. A single asterisk indicates the partial avoidance of $\mathrm{X}$-inactivation. A double asterisk indicates full escape from $\mathrm{X}$-inactivation whilst an i indicates inactivation. A question mark indicates uncertainty, typically because activity has yet to be shown directly or because there exist contradictory results. Xist is the $\mathrm{X}$-inactivation initiation site and is active on the inactive $\mathrm{X}$ but inactive on the active $\mathrm{X}$. $\pi$ indicates presumed pseudogene/silent gene status. If a Y-linked homologue of an X-linked gene is not indicated then such a Y-linked homologue has yet to be detected (except human GS1 which has a Y-linked analogue but of unknown location (though it is probably in Yq11)). Note that linkage of ANT2 is uncertain but lies somewhere between Xq13 and $\mathrm{Xq} 26$. Genes included are $Z F X / Y$, zinc finger on the $\mathrm{X} / \mathrm{Y} ; R P S 4$, ribosomal protein subunit 4; UBE1, ubiquitin-activating enzyme $1 ; A M G$, amelogenin; $K A L I G$, Kallmann's syndrome; STS, steroid sulphatase; $M I C 2$, antigen defined by monoclonal 12E7; ANT2/3, ADP/ATP translocase type 2/3;XG, Xg surface antigen (blood group); SRY, sex-region on the Y. GS1 and DXS423 are transcripts of unknown function. Mouse Y-map after Bishop (1992). Mouse X map after Brown et al. (1992). Human X map based on Davies et al. (1991) and Ballabio \& Willard (1992). For linkage of human Y-linked genes, see relevant references in the text. For X-linked activity status see Ballabio \& Willard (1992) and relevant references in the text.

probably mediated by KALIGl's involvement in the activity of luteinizing hormone-releasing hormone's secretion. As discussed below (and in Haig, 1993), luteinzing hormone homologues are believed to be involved in maternal/foetal conflicts.

It is unclear whether all of the genes that escape $\mathrm{X}$-inactivation act (or could act) as growth factors. GS1 and DXS423 (cited in Ballabio \& Willard, 1992) are of unknown function (but note expression of GS1 in placental tissue: Yen et al., 1992). The $X G$ gene product is a cell surface antigen (though note, as above, that $M I C 2$, whose product is also a cell surface antigen, is associated with carcinoma). Even if the products were not growth-related, a role in maternal foetal conflict could not be ruled out as such conflict can be immune-mediated (Hurst, 1993; Peters \& Barker,
1993). The possible relationship between immunemediated maternal/foetal conflict and escape from $\mathrm{X}$-inactivation is, however, unclear. One might, for instance, predict that a foetus could be selected to express only its maternally derived antigens and hence not evoke an antibody response. In contrast, however, in the case of murine severe combined anaemia and thrombocytopenia, the presence of a paternally derived gene, identical to the selfish one in the mother, is adequate to save the foetus and hence in this instance both alleles should be expressed if possible (Peters \& Barker, 1993).

The classical model also predicts that those genes that escape $\mathrm{X}$-inactivation are more often than not those involved in foetal growth (as foetal growth is often rapid). However, the time-frame/high expression 
argument would also predict that genes involved in short time-frame events in adulthood but not in foetuses should also avoid $\mathrm{X}$-inactivation. I could find no example of a gene avoiding $\mathrm{X}$-inactivation that was expressed only in mature individuals. The classical model might, however, explain this in terms of the absence of the necessary conditions.

The validity of both the classical and the conflictbased hypotheses is in some part confused by the ghost of autosomal linkage past. Could the avoidance of $\mathrm{X}$-inactivation simply be a side-product of a recent history of autosomal or pseudoautosomal linkage and hence non-dosage-compensated expression? For instance, $M I C 2$, like other human PAR genes, avoids inactivation (Smith et al., 1993). Many of the genes that avoid inactivation, though not pseudoautosomal, are very close to the PAR boundary (Fig. 1). If these near PAR examples used to be PAR-linked, then might these examples be nonproblematical?

At least four of the genes avoiding $\mathrm{X}$-inactivation ( $A M G, S T S, K A L I G$ and $Z F X$ ), locate to the region of the $\mathrm{X}(\mathrm{XAR})$ that was autosomally derived at the time of evolution of the eutherians (between 80 and 150 million years ago) (Lanfear \& Holland, 1991; Mitchell et al., 1992; Watson et al., 1993). The Y-linkage of these genes' homologues cannot hence be accountable to the prototype (pre-eutherian) mammalian $Y$ possessing them. Whether the XAR was ever pseudoautosomal is an unresolved issue. Were the XAR never pseudoautosomal (and hence never Y-linked) then the movement of the genes on to the $\mathrm{Y}$ would probably require some nonhistorical explanation. Nonindependence of $\mathrm{X}$ and $\mathrm{Y}$-linked zinc finger genes (Hayashida et al., 1992; Pamilo \& Bianchi, 1993) demonstrates that gene transfer has occurred between $\mathrm{X}$ and $\mathrm{Y}$ independently of any chromosomal translocations. Were the XAR originally pseudoautosomal, then the location of Y homologues of the XAR genes could be explained by the spread of the new PAR such that all Ys and all Xs had the new PAR. Y-linkage of homologues would then be due to movement of the pseudoautosomal boundary. However, even if the XAR was originally PAR-linked it would seem necessary to present a model to account both for the conversion of the domain to a non-pseudoautosomal region and for the persistence of particular XAR genes on the Y. The loss of Y-linked genes is less of a problem than persistence as Y-linked sequences are expected to decay through a Muller's ratchet-like process. In sum, a historical argument does not solve the problem of the escape from $\mathrm{X}$-inactivation.

All of the above assumes that the PAR is simply a fact of mammalian $\mathrm{X} / \mathrm{Y}$ chromosomes and that avoidance of X-inactivation is a fact of PAR linkage. However, a PAR is not found in marsupials (see Ellis and
Goodfellow, 1989, for discussion). Clearly then the PAR is not necessarily required for $\mathrm{X}-\mathrm{Y}$ segregation at meiosis as might be supposed. It could be conjectured that the evolution of the PAR is intimately related to the evolution of placentation (as indeed the transfer of XAR might be). This issue will be left for future work. Further, in mice, PAR genes do not avoid X-inactivation (e.g. Sts: Jones et al., 1989; but see Keitges \& Gartler, 1986; Zfx, Rps4x: Ashworth et al., 1991 and Ubelx: Bressler et al., 1993). Hence, avoidance of $\mathrm{X}$-inactivation need not be a simple property of a recent past as an autosomal or PAR gene.

As indicated above there is turnover of both $\mathrm{X}$ inactivation status and of chromosomal location of individual genes. Why might there be turnover in the avoidance of $\mathrm{X}$-inactivation and in the movement of the PAR? The classical view would propose that the variation in expression is due to variation in growth rates. The conflict-based view can suggest that turnover is expected because of a co-evolutionary arms race between suppressor and selfish gene. The variation between species lineages in the patterns of activation of X-linked sequences, in the possible movement off (e.g. Ubelyl) and on to (eg MIC2, Zfy, Amg, Sts, Kalig) the Y, and in movement between NPAR and PAR (Sts is pseudoautosomal in mice but not in humans: Fraser et al., 1987) might all be the result of conflicts of interest between $\mathrm{X}$ and $\mathrm{Y}$. This hypothesis predicts a higher rate of movement to and from the $Y$ and of change in $\mathrm{X}$-inactivation status for growthrelated genes than for non-growth-related genes.

\section{Suppression could give rise to an arms race: a rationale for variation in copy number of $Z F Y$ and for fast evolution of $S R Y$}

Suppression may also be mediated by directly inhibiting the effect of the selfish Y. Were the mother to have a mutant gene capable of suppressing the selfish foetal $\mathrm{Y}$ genes, this mutant could spread. Suppression in this context may just mean nonresponse to the males' excess demands. Maternally derived genes in the foetus with male-specific expression that were capable of suppressing the selfish Y could also spread. As an $\mathrm{X}$ is maternally derived two-thirds of the time, assuming all else is equal, suppressors will be more likely to accumulate on an $\mathrm{X}$ than on an autosome (NB all is not, however, equal as there are more autosomes than Xs). Perhaps significantly then, whereas the size of human male offspring at birth negatively correlates with the number of $X$ chromosomes (Chen et al., 1971), in females the same pattern does not hold (Chen et al., 1971). This indicates that the $X$ chromosome in males acts to reduce foetal growth as might be expected of a chromosome that could be selected to oppose growth 
demands of the paternally derived chromosome set. Genes on the murine $\mathrm{X}$ that control growth have also been demonstrated (Thornhill \& Burgoyne, 1993).

After suppression of the Y-linked selfish gene, a mutant version of the $Y$ gene that could escape suppression could once again spread. In turn, a new form of suppressor could spread, and so on. This arms race could be mediated by variation in dosage (cf. Hurst, 1992) of the growth factor or by modification of sequence (or both). Within mammalian species lineages there is much variation in copy number of $Z f y$ consistent with a dosage-mediated arms race. In Cricetid rodents, Zfy copy number varies from one to 24 copies and variation in copy number is clade-dependent (Bianchi et al., 1992). Myopus schisticolor has up to 15-16-fold amplification in copy number of Zfy (Lau, cited in Bianchi et al., 1992). The above figures are minimum estimates. The significance of the fact that some of the above represented species have $\mathrm{XY}$ females in natural populations is not understood.

The above hypothesis for variation in copy number predicts that $Z f y$ could act as a dosage-dependent growth factor. It also predicts that if this is so, and that at equilibrium the multiple copies have no net effect on growth, then the multiple copies of $Z f y$ should have their effect annulled by some unlinked genes. The variation in clades in $Z f y$ copy number should then be matched by some variation in the activity of the putative suppressor.

If the arms race is mediated by modification of sequence then potentially rapid sequence divergence between independent species lineages is to be expected. Both Whitfield et al. (1993) and Tucker \& Lundrigan (1993) report rapid sequence evolution of $S r y$, the Y-linked mammalian testis determining factor (Koopman et al., 1991). The ratio $\left(K_{\mathrm{A}} / K_{\mathrm{S}}\right)$ of nonsynonymous to synonymous substitutions between human Sry and that of other primates is up to 1.88. A 'usual' figure for $K_{\mathrm{A}} / K_{\mathrm{S}}$ is between 0.05 and 0.2 . In a comparison of 363 genes between mouse and rat, Wolfe \& Sharp (1993) reported only one sequence with $K_{\mathrm{A}} / K_{\mathrm{S}}$ greater than unity (this being interleukin-3) and an average ratio of 0.14 . Wolfe \& Sharp's survey did not include Y-linked sequences. Tucker \& Lundrigan (1993), in comparing Sry of Mus musculus with that in six species of old world mice or rats, found $K_{\mathrm{A}} / \mathrm{K}_{\mathrm{S}}$ values between 0.33 and 0.45 . Most of the variation within the $S r y$ sequence is in domains outside the central HMG box (a DNA binding domain). The non-HMG domains within the open reading frame of Sry I shall refer to as flanking domains. Within the mammals as a whole there is much variation in the size of the flanking domains (Whitfield et al., 1993).

Why should evolution of $S r y$ in the flanking sequences be so rapid? At first sight this is just the pattern that is not expected: once a species has found a means to make a male, why change it? Two possible reasons for the rapid evolution can be sketched. Variation in the flanking domains may be either approximately neutral (and unconstrained), or under strong directional selection. Tucker \& Lundrigan (1993) argue that, as human Sry cannot act in mice, the lack of constraint argument is possibly inappropriate. Unconstrained (perfectly neutral) selection would result in a $K_{\mathrm{A}} / K_{\mathrm{S}}$ value of one. Hence, a value as high as 1.88 (human/chimp comparison) can probably not be explained in neutral terms. Whitfield et al. (1993) note that the monomorphism within each species for Sry is consistent with both interpretations and is best interpreted as evidence for a rapid sweep through the population of one variant of Sry. However, simply because one variant has swept through does not mean that that Sry variant is under selection. With the absence of recombination on the NPAR Y, any NPAR Y-linked gene that is being selected will sweep through a population and all the genes linked to it will hitch-hike with it.

Whitfield et al. (1993) note that fast evolving sequences are often associated with genomic conflict, such as that between host and parasite (Hughes \& Nei, 1988; Hughes et al., 1990; Hughes, 1991; see also Hill \& Hastie, 1987; Vacquier \& Lee, 1993). Conflicts within genomes and between genomes of organisms of the same species might also be suspected (Whitfield $e t$ al., 1993). The above model for the fast evolution of Y-linked sequences suggests a possible conflict-based model for the rapid evolution of Sry. The model would propose that $S r y$ does or could act as a growth promoter/sex ratio distorter. At equilibrium, this growth-promoting effect is somehow countered, at least in part, by an unlinked gene in either the foetus or mother. Note also that whereas other Y-linked genes could be countered by $\mathrm{X}$-linked homologues avoiding $\mathrm{X}$-inactivation, $\mathrm{Sry}$ is unusual in that an X-linked homologue would interfere with sex determination and hence be an invalid response to the spread of a selfish Sry. In principle any sex ratio-distorting selfish gene could be the cause of rapid evolution of Sry. Alternative selfish genes are discussed by Burt \& Trivers (in preparation).

The arms race component of the theory predicts that this suppressor could also have a high rate of evolution. If the suppressor, rather than being dependent simply upon a DNA sequence (for binding of SRY for instance), has its effects by the production of a protein, then this protein sequence is expected to show a high nonsynonymous to synonymous substitution ratio, and one that approximately matches that for SRY in the same species comparison.

The ideal test of the model would be to follow mutant versions of Sry as they spread in their respec- 
tive populations. The model makes clear predictions about the reason for the spread. Those with the spreading version of Sry should, for instance, have an advantage at the foetal stage (because of greater resource extraction from the mother) and/or the progeny sex ratio should be male-biased.

Weak circumstantial evidence can be raised to suggest that Sry might be involved in sex ratio effects (Hurst, 1994, this issue). Circumstantial evidence can also be raised to support Sry's role as a growth factor. $S r y$ is expressed in prostate cancer (Tricoli et al., 1993a) and in renal cell carcinoma (Tricoli et al., 1993b) and hence its inappropriate expression is linked with growth. Significantly, Tricoli et al. (1993b) suggest that Sry may be an activator of oncogenes. This would be consistent with its expression in spermatids (Hendriksen et al., 1993) were such expression a means to achieve an early zygotic growth advantage, as has been suggested for postmeiotic proto-oncogene expression (Moore \& Haig, 1991; see also Hurst, 1994, this issue). However, most direct manipulations of $S r y$ indicate that it does not have an obvious growth effect. First, deletion of Sry has no effect on growth. Second, transfer of Sry from Y to X (XXSry) also has no effect on growth. Third, XYSry (hence with two copies of $S r y$ ) embryos are no larger than XY embryos. These data, however, compare surviving individuals and hence do not rule out a net advantage. If Sry has a net growth effect (including an increased probability of implantation and/or maintenance) this would thus not be revealed by the above comparisons.

The above experimental results may be compatible with a growth effect if Sry has a suppressor as the theory presumes. A suppressor of Sry on the human X has been demonstrated and has been narrowed down within distal Xp (Ogata et al., 1992 and references therein). Individuals that are $\mathrm{XYp}+$ with normal Sry and two active copies of the $\mathrm{Xp}$ gene(s) are hence female (Coles et al., 1992; Maaswinkel-Mooij et al., 1992). If it is assumed that this gene has no other function than the suppression of Sry then it is hard to account for its presence in conventional terms: in XX individuals its suppressing activity would not be required, while in $\mathrm{XY}$ individuals it would not be desired. The presence of the suppressor may thus be evidence in favour of the conflict-based model. However, two problems reduce the value of this evidence. First, that two copies of Sry have no growth effect suggests that any suppressor must be dosage independent, but the Xp suppressor is probably dosage dependent. Second, it might be the case that the $\mathrm{Xp}$ gene(s) may have some necessary role (apart from the suggested suppression of Sry-mediated growth effects), in which case its existence is neither evidence for nor against the above model. It may, for instance, be the case that the mammalian default sex determining strategy is to be male. Were this the case then Sry might be male determining by suppressing the $\mathrm{Xp}$ gene's feminizing effect (see McElreavey, 1993, for a related model). Although such a model would indicate that the presence of the suppressor is not evidence in favour of the conflict-based model, the possibility remains that the Xp gene(s) suppress the putative growth effects of Sry. Were the Xp gene(s) the suppressor of the putative selfish effects of Sry through all the mammals, then it should show rapid sequence evolution (and possibly variation in copy number as well). The rate of sequence evolution through different clades should match that of Sry, the predicted patterns of which are discussed below. Note also that, as Burt \& Trivers (in preparation) point out, if the sex ratio is male-biased (as might be expected were a Y-linked selfish gene spreading), a suppressor that prevented Sry from inducing masculinity could spread as it would act to equalize the sex ratio. This assumes, however, that XY females are adequately fertile. In humans $X Y$ females are not fertile whilst in mice and lemmings they can be.

An alternative (and possibly better) test of the model is to consider variation in the rate of evolution across and within clades. The model predicts that within a group there may be variation in rate as a function of the degree of female promiscuity. If most of the competition between foetuses is between those within a brood, then the theory predicts that those species with identical offspring in every brood (e.g. the armadillo) should have a much slower rate of sequence evolution of Sry than the average. Monogamous or nearly monogamous mammals would be expected to have slow sequence evolution. The fastest rates are to be expected in those groups in which a brood contains as many paternally unrelated offspring as possible. Those instances in which there is multiple paternity across broods may also be expected to show fast evolution. The relative importance of within and between brood relatedness heterogeneity is left for future study.

The available data are limited but generally consistent with this prediction. Whitfield et al. (1993) calculate $K_{\mathrm{A}} / K_{\mathrm{S}}$ values for seven primate/human comparisons. The two species with the highest $K_{\mathrm{A}} / K_{\mathrm{S}}$ (ranked 1 and 2 in descending order of $K_{\mathrm{A}} / K_{\mathrm{S}}$ value) are the ones in which the females have the most mates (chimps and pygmy chimp). The remaining species have $K_{\mathrm{A}} / K_{\mathrm{S}}$ values considerably lower than these top two. Gibbons and marmosets are typically monogamous while gorilla females are nearly always monopolized by a single male. These three rank 4,5 and 7 respectively (out of a list of seven). The orang-utan ranks 3 and has a single-male mating system but possibly one with some degree of multiple mating, as 
indicated by their proximity to the testis weight/body size regression line (Harcourt et al., 1981). It is unclear whether the baboons (ranked 6) fit the above distribution. The species of baboon used is not given by Whitfield et al. and there is variation between baboon species in mating system. Most, however, live in multimale colonies and are thus assumed to have multiple paternity. Were this so it would not conform to the pattern. It would be instructive to have information on the relatedness between progeny in all the above species. It is assumed in the above analysis that $K_{A} / K_{\mathrm{S}}$ controls for time-dependent effects.

An ideal comparative test of the hypothesis would be to follow Sry through time and see if bursts in selective substitutions (preferably controlling for amino acid similarity) are associated with a decreased probability that any two progeny are paternally related. This would, for instance, appear to be the case at the human/gorilla/chimp trifurcation. These three species separated almost synchronously a little under 10 million years ago. The pigmy chimp separated from the chimp lineage around one million years ago. Gorilla and human Sry are not very different, but chimp/pigmy chimp Sry are both different from the human sequence. The most parsimonious explanation of this would be a burst of substitutions in the chimp/pigmy chimp lineage. As noted above, both of these species are considerably more polygamous than either humans or gorillas.

Were a growth/sex ratio effect the cause of rapid sequence evolution, then the above theory would also predict that the rate of evolution of Sry could be faster in groups in which the offspring has greater potential to manipulate the mother as regards resource extraction. There are at least two ways to predict whether the offspring could manipulate the mother. First, one can extrapolate from the physical connections between mother and foetus. Second, if Haig's theory of imprinting is correct, and if the evolution of Sry was also mediated by foetal/maternal conflict, then we can predict that those mammals with imprinting will also have fast evolving Sry.

Because of the ability of early-implanting offspring to prevent implantation of others, the intimate contact between mother and offspring and the ability to control the degree of milk extracted from a mother, a selfish $Y$ is expected to have relatively trivial conditions for invasion on the eutherian Y. In marsupials, although there is no placental contact, the young does, however, attach to and suckle at the mothers nipple. The author is unaware of reports of an ability of fast developing zygotes to interfere with slower ones prior to nutrient allocation. If increased suckling (or any other manipulation) can force the mother to provision a foetus with more resources than the mother would prefer to allocate, then Sry might be able to exercise some selfish effect. Although no autosomal genes with imprinting have been identified in marsupials the paternal $\mathrm{X}$ chromosome is inactivated. Whereas in eutherians paternal $\mathrm{X}$-inactivation is restricted to the extraembryonic tissues (i.e. the sites of contact between foetus and mother), in metatheria the $\mathrm{X}$-inactivation is most pronounced in muscle. This suggests the possibility that a dominant mode of conflict in metatheria could be mediated by the intensity of suckling (Moore \& Haig, 1991). The human imprinting disorders Prader-Willi syndrome and Angelman syndrome involve modifications of the intensity of suckling. Maternal deletions cause excessive suckling whereas paternal deletions cause under-suckling, as would be predicted (Moore \& Haig, 1991). It is thus reasonable to suppose that maternal-foetal conflict probably does exist in metatherians although it is probably not as subtle as it is in eutherians. Hence, if Sry activity could affect the intensity of suckling, then moderately rapid sequence evolution of $S r y$ would be predicted in marsupials.

Two marsupials, Sminthopsis macroura (Order Polyprotodonta, Family Dasyuridae) and Macropus eugenii (Order Diprotodonta, Family Macropodidae) have had their Sry sequence analysed (Foster et al., 1992). Within the HMG box both marsupial genes show extensive homology to human sequence (an average of 67 per cent identity and 84 per cent similarity). No significant homology could be detected between the human and marsupial proteins outside the HMG box. Homology between the two marsupial genes reaches 84 per cent with conservative substitutions, but falls below 50 per cent outside the HMG box. Whether this is indicative of evolution as fast as in eutherians is unclear as the time from common ancestry of the two marsupials is unknown.

In monotremes the young consume milk that is secreted diffusely over the skin. This system would appear to be hard to manipulate and hence it is predicted that monotremes should have slow sequence evolution of $S r y$ (NB this assumes that promoting the rate of early development is also not a means to gain advantage in monotremes). To the best of the author's knowledge there is no evidence of imprinting in monotremes. Unfortunately, there are only two extant monotreme genera (the duck-billed platypus and the echidna) and hence a significant statistic will be difficult to obtain.

Bird embryos, whilst in the egg, have no opportunity to manipulate their mother as they are simply provisioned with a fixed amount of yolk. Hence the avian sex-determining locus (presumably W-chromo- 
some linked) need not be fast evolving. Unfortunately the avian sex-determining locus has yet to be identified although a conserved W-linked gene has been identified (Halverson \& Dvorak, 1993). Sry-like sequences are known in birds but these are not sex-linked. The above theory would predict that these sequences would not be fast evolving. Were they rapidly evolving then this fast evolution would be a property of $S r y$ independent of its position on the mammalian Y. These data are not yet available (R. Griffiths, pers. comm.). Were they slow evolving this would indicate that either the $\mathrm{Y}$ positioning or some covarying factor (e.g. a role in sex determination) should be implicated. Sry-like genes (the SOX family) in mammals are not fast evolving (Whitfield et al., 1993).

There exist at least three other reasons why Y-linked genes might evolve rapidly. As Hamilton (1967) notes, Y-linked meiotic drive genes could spread and evolve faster than a similar gene with a male-specific effect that was on the $X$ or an autosome. This is simply because an $X$ spends on the average only one-third of its time in a male whereas the $\mathrm{Y}$ is always in a male. By the same logic, a resource acquisition gene on the $Y$ will spread more rapidly than a selfish resource acquisition gene on the $\mathrm{X}$ (i.e. a gene that attempts to boost resource uptake only when it is paternally derived). Autosomal genes should have intermediate rates as a given autosomal gene spends half its time being transmitted by a male.

In a related vein, as Haldane (1947) first noted, if males act as mutation generators the above difference in the rate of evolution of $\mathrm{X}, \mathrm{Y}$ and autosomes can be accentuated. This difference in mutation rate is probably because spermatogenesis (and the process leading up to it) involves more cell divisions than oogenesis (Miyata et al., 1987). Empirical data are consistent with a higher mutation rate in males than in females, at least in mammals (Miyata et al., 1987; Shimmin et al., 1993). It is this process that most probably accounts for the absolute high rate of synonymous substitutions in Y-linked compared to X or autosomal sequences (see Charlesworth, 1993, for review).

Similarly, Y-linked sequences may accumulate slightly deleterious mutations at a high rate because the $Y$ does not recombine (except in the pseudoautosomal region) and hence Muller's ratchet and related processes are expected to act more rapidly (Charlesworth, 1991, 1993). The above two explanations (Muller's ratchet and males as mutation generators) are not competent to explain the dramatic nonsynonymous substitution rate of Sry.

Whitfield et al. (1993) suggested that fast evolution of Sry could lead to hybrid disruption due to inappropriate sexual development. That transgenic mice with human Sry are not sex-reversed (Koopman et al.,
$1991)$ is consistent with inappropriate expression of Sry in novel contexts. Although hybrid zone reinforcement might act to accelerate sequence evolution to some degree, fast sequence evolution of Sry prior to any reinforcement would be required for such isolation to occur. If the above model for the fast evolution of Sry is correct, and if Whitfield et al. are correct to suppose a possible role in hybrid disruption, then Sry will be a further addition to the list of postzygotic isolation genes whose divergence was due to genetic conflicts (Hurst, 1993; Pomiankowski \& Hurst, 1993, for references).

\section{Do other genes involved in maternal-foetal conflict show rapid sequence evolution?}

If co-evolution between growth factor and suppressor were the cause of the rapid sequence evolution of Sry then it should be the case that other growth factors involved in maternal/foetal relations are fast evolving. Haig (1993) argues that the products secreted by mammalian foetuses into the maternal blood system are typically to manipulate the mother into providing greater foetal provisioning. He postulates, for instance, that human chorionic gonadotropin ( $\mathrm{hCG}$ ) is involved in maternal/foetal conflicts. This involvement, he argues, is the reason for its fast evolution and divergence from its presumed ancestral protein human luteinizing hormone $(\mathrm{hLH})$. Both hLH and hCG are dimeric glycoproteins. They share a common $\alpha$ subunit but possess different $\beta$-subunits that are encoded by closely linked autosomal genes. There are six known hCG $\beta$ genes and at least one of them is expressed in the placenta (Bo \& Boime, 1992). The ancestral hCG $\beta$ was probably derived from $\mathrm{hLH} \beta$ by two frame-shift mutations. The consequence of these mutations was the addition of a 24 amino acid tail to the C-terminus. Importantly, Haig notes, hCG $\beta$ and $\mathrm{hLH} \beta$ share only about 80 per cent amino acid identity, and their nucleotide sequences show a high proportion of nonsynonymous to synonymous changes (Talmadge et al., 1984). Intron sequence divergence appears to have gone on at about the same rate as the silent substitutions.

Haig also proposes that if foetal demands went unopposed, the foetus would, for instance, remove more glucose from maternal blood than was in maternal interests. He suggests that the mother's best interests are served by reducing her blood sugar to limit foetal uptake. Further, he argues that a mother and her foetus will compete after every meal for control of the blood sugar. Whereas the mother would prefer to take sugar out of the blood rapidly, the foetus would prefer that the sugar remained in circulation and hence could be taken across the placenta. This conflict 
between mother and foetus has resulted, Haig proposes, in an evolutionary arms race in which a trait permitting a foetus to increase its output of anti-insulin hormone (keeping blood sugar high) will spread, and in response a trait which sees the mother increase her production of insulin (reducing blood sugar levels) can also spread. The product of the arms race is a very high foetal production of an anti-insulin hormone and an equally high maternal production of insulin. The high production of these two hormones has practically no net effect on the flow of sugars into the foetus as the two effects cancel each other out.

In mechanistic terms placental lactogen (PL) and placental growth hormone (PGH) are proposed to be the foetal anti-insulin hormones. PL is the most abundant peptide hormone produced by humans and other primates. Its concentration in maternal serum increases throughout pregnancy, reaching the remarkably high titre of 5-15 $\mu \mathrm{g} \mathrm{mL}^{-1}$ near term. At this stage the syncytiotrophoblast is secreting $1-3 \mathrm{~g}$ per day. For comparison, the plasma concentration of $\mathrm{GH}$, integrated over a day, is about $0.003-0.006 \mu \mathrm{g} \mathrm{mL}^{-1}$ in young nonpregnant adults (Daughaday, 1989). Levels of PGH are much lower than those of PL, but follow a similar temporal pattern. At term their levels exceed $0.015 \mu \mathrm{g} \mathrm{mL}^{-1}$. As expected, concentrations of PL and PGH in foetal serum are much lower than concentrations in maternal serum (Frankenne et al., 1988; Eriksson et al., 1989; Walker et al., 1991). Haig (1993) details further evidence consistent with the involvement of placental lactogens in maternal/foetal conflict.

If placental lactogens are the foetal means to manipulate sugar uptake then we might expect rapid evolution of these sequences. In confirmation, recently Wallis (1993) has found that placental lactogens of ruminants evolve at a 'remarkably high rate' with a $K_{\mathrm{A}}$ / $K_{\mathrm{S}}$ value of 1.75 . Similarly, a comparison between murine and rat placental lactogens I and II reveals $K_{\mathrm{A}}$ $K_{\mathrm{S}}$ values of 0.42 and 0.41 , respectively. While these values are not as high as those for ruminants they are nonetheless significantly greater than the average of $0.14(n=363)$ found in the mouse/rat comparison (Wolfe \& Sharp, 1993). Protein identity for PLI and PLII across this comparison is 74.9 per cent and 77.8 per cent, respectively, which compares with an average of 93.9 per cent $( \pm 8.1 ; n=363$ ) (Wolfe \& Sharp, 1993). Of the 363 proteins only 15 ( 4 per cent) had a lower percentage identity than that for PLI and $23<6.3$ per cent) had a lower identity than PLII. In sum, it is reasonable to suppose that maternal/foetal interactions could be responsible for rapid sequence evolution of foetal growth factors, of which Sry may be one example.

\section{Acknowledgments}

I wish to particularly thank Dr Paul Burgoyne for assistance. I should also like to thank Professors Peter Goodfellow, Brian Charlesworth and Chris Graham, Drs Jamie Foster, Simon Whitfield, Alan Schafer, Peter Holland, Richard Griffiths, Katrina Mangin, Andrew Pomiankowski, Andy Purvis, Eddie Holmes, Marion Petrie, Rosie Woodruffe, Amanda Vincent, David Haig and Alan Grafen. This research was funded by the Royal Society Horace Le Marquand and Dudley Bigg Research Fellowship and The Browne Research Fellowship at The Queen's College, Oxford.

\section{References}

ASHWORTH, A., RASTAN, S., LOVELL-BADGE, R. AND KAY, G. 1991. $\mathrm{X}$-chromosome inactivation may explain the difference in viability of XO humans and mice. Nature, 351, 406-408.

BALlabio, A. AND WILlARD, H. F. 1992. Mammalian X-chromosome inactivation and the XIST gene. Curr. Opin. Gen. Dev., 2, 439-447.

BIANCHI, N. O., BIANCHI, M. S., PAMILO, P., VIDAL-RIOJA, L. AND DE LA CHAPELLE, A. 1992. Evolution of zinc finger-Y and zinc finger-X genes in Oryzomyne-Akodontine rodents (Cricetidae). J. Mol. Evol., 34, 54-61.

BISHOP, C. E. 1992. Mouse Y chromosome. Mammal. Genome, 3, S289-S293.

Bo, M. AND BoIME, I. 1992. Identification of the transcriptionally active genes of the chorionic gonadotropin $\beta$ gene cluster in vivo. J. Biol. Chem., 267, 3179-3184.

BRESSLER, S. L., LEE, K. H., ADLER, D. A., CHAPMAN, V. M. AND DISTECHE, C. M. 1993. Maintenance of X inactivation of the Rsp4, Zfx and Ubel genes in a mouse in vitro system. Som. Cell Mol. Genet., 19, 29-37.

BROWN, S. D. M., AVNER, P. AND HERMAN, G. E. 1992. Mouse X chromosome. Mammal. Genome, 3, S274-S288.

BURT, A. AND TRIVERS, R. Genes in Conflict. Harvard University Press, Cambridge, MA (in preparation).

CHARLESWORTH, B. 1991. The evolution of sex chromosomes. Science, 251, 1030-1033.

CHARLESWORTH, B. 1993. More mutations in males? Current Biol., 3, 466-467.

CHEN, A. T. L., CHAN, Y. K. AND FALEK, A. 1971. The effects of chromosome abnormalities on birth weight in man. I Sex chromosome disorders. Human Hered., 21, 543-556.

COLES, K., MACKENZIE, M., CROLLA, J., HARVEY, J., STARR, J., HOWARD, F. AND JACGBS, P.A. 1992. A complex rearrangement associated with sex reversal and the Wolf-Hirschorn syndrome: a cytogenetic and molecular study. J. Med. Genet., 29, 400-406.

DAUGHADAY, w. H. 1989. Growth hormone: normal synthesis, secretion, control, and mechanisms of action. In: DeGroot, L. J. (ed.) Endocrinology, 2nd edn, pp. 318-329. W. B. Saunders, Philadelphia.

DAVIES, K. E., MANDEL, J. L., MONACO, A. P., NUSSBAUM, R. L., WILlARD, H. F. 1991. Report of the committee on the 
genetic constitution of the $\mathrm{X}$ chromosome: human gene mapping 11. Cytogenet. Cell Genet., 58, 853-966.

DISTECHE, C. M., ZACKSENHAUS, E., ADLER, D. A., BRESSLER, S.L, KEITZ, B. T. AND CHAPMAN, v. M. 1992. Mapping and expression of the ubiquitin-activity enzyme E1 (Ubel) gene in the mouse. Mammal. Genome, 3, 156-161.

ELLIS, N. AND GOODFELLOW, P. N. 1989. The mammalian pseudoautosomal region. Trends Genet., 5, 406-410.

ERIKSSON, L., FRANKENNE, F., EDĖN, S., HENNEN, G. AND VON SCHOULTZ, B. 1989. Growth hormone 24-h serum profiles during pregnancy - lack of pulsatility for the secretion of the placental variant. Br. J. Obstet. Gynaecol., 96, 949-953.

FELLINGER, E. J., GARIN-CHESA, P., GLASSER, D. B., HUVOS, A.G. AND RETTIG, W. J. 1992. Comparison of cell surface antigen HBA71 (p30/32MIC2), neuron-specific enolase, and vimentin in the immunohistochemical analysis of Ewing's sarcoma of bone. Am. J. Surg. Pathol., 16, 746-755.

FISHER, E. M. C., BEER-ROMERO, P., BROWN, L. G., RIDLEY, A., McNEIL, J. A., LAWRENCE, J. B., WILLARD, H. F., BIEBER, F. R. AND PAGE, D. C. 1990. Homologous ribosomal protein genes on the human $\mathrm{X}$ and $\mathrm{Y}$ chromosomes: escape from $\mathrm{X}$ inactivation and possible implications for Turner Syndrome. Cell, 63, 1205-1218.

FOSTER, J. W., BRENNAN, F. E., HAMPIKIAN, G. K., GOODFELLOW, P. N., SINCLAIR, A. H., LOVELL-BADGE, R., SELWOOD, D. W. AND MARSHALL GRAVES, J. A. 1992. Evolution of sex determination and the Y chromosome: $S R Y$-related sequences in marsupials. Nature, 359, 531-533.

FRANKENNE, F., CLOSSET, J., GOMEZ, F., SCIPPO, M. L., SMAL, J. AND HENNEN, G. 1988. The physiology of growth hormones (GHs) in pregnant women and partial characterization of the placental GH variant. J. Clin. Endocrinol. Metab., 66, 1171-1180.

Fraser, N., Ballabio, A., Zollo, M., Persico, G. AND CRAiG, I. 1987. Identification of incomplete coding sequences for steroid sulphatase on the human Y chromosome: evidence for an ancestral pseudoautosomal gene? Devel. Suppl. 101, 127-132.

GOODFELLOW, P. N. AND TIPPETT, P. 1981. A human quantitative polymorphism related to $\mathrm{Xg}$ blood groups. Nature, $\mathbf{2 8 9}$, 404-405.

GOODFELLOW, P. PYM, B., MOHANDAS, T. AND SHAPIRO, L. J. 1984. The cell surface antigen locus, $M I C 2 X$, escapes X-inactivation. Am. J. Hum. Genet., 36, 777-782.

HAIG, D. 1993. Maternal-fetal conflict in human pregnancy. Q. Rev. Biol., 68, 495-532.

HALDANE, J. B. S. 1947. The mutation rate for haemophilia and its segregatation ratios in males and females. Ann. Eugen., 13, 262-271.

HALVERSON, J. L. AND DVORAK, J. 1993. Genetic control of sex determination in birds and the potential for its manipulation. Poultry Sci., 72, 890-896.

HAMILTON, W. D. 1967. Extraordinary sex ratios. Science, 156, 477-488.

HARCOURT, A. H., HARVEY, P. H., LARSON, S. G. AND SHORT, R. V. 1981. Testis weight, body weight and breeding system in primates. Nature, 293, 55-57.
HAYASHIDA, H., KUMA, K. AND MIYATA, T. 1992. Interchromosomal gene conversion as a possible mechanism for explaining divergence patterns of ZFY-related genes. $J$. Mol. Evol., 35, 181-183.

HENDRIKSEN, P. J. M., HOOGERBRUGGE, J. W., VAN DER LENDE, T. AND GRootegoed, J. A. 1993. Transcription of the X and Y chromosomes in mouse spermatids. J. Reprod. Fertil., 12, 12.

HILL, R. E. AND HASTIE, N. D. 1987. Accelerated evolution in the reactive centre regions of serine protease inhibitors. Nature, 326, 96-99.

HUGHES, A. L. 1991. Circumsporozoite protein genes of malaria parasites (Plasmodium spp.): evidence for positive selection on immunogenic regions. Genetics, 127, 345-353.

HUGHES, A. L. AND NEI, M. 1988. Pattern of nucleotide substitution at major histocompatibility complex class I loci: evidence for overdominant selection. Nature, 335, 167-170.

HUGHeS, A. L., OTA, T. AND NEI, M. 1990. Positive Darwinian selection promotes charge profile diversity in the antigen binding cleft of class I MHC molecules. Mol. Biol. Evol., 7, 515-524.

HURST, L. D. 1992. Is Stellate a relict meiotic driver? Genetics, 130, 229-230.

HURST, L. D. 1993. scat $^{+}$is a selfish gene analogous to Medea of Tribolium castaneum. Cell, 75, 407-408.

HURST, L. D. 1994. Embryonic growth and the evolution of the mammalian $\mathrm{Y}$ chromosome. I. The $\mathrm{Y}$ as an attractor for selfish gene factors. Heredity, 73, 223-332

JONES, J., PETERS, J., RASBERRY, C. AND CATTANACH, B. M. 1989. $\mathrm{X}$-inactivation of the Sts locus in the mouse: an anomaly of the dosage compensation mechanism. Genet. Res., 53, 193-199.

KEITGES, E. AND GARTLER, S. M. 1986. Dosage of the Sts gene in the mouse. Am. J. Hum. Genet., 39, 470-476.

KOOPMAN, P., GUBBAY, J., VIVIAN, N., GOODFELLOW, P. AND LOVELLBADGE, R. 1991. Male development of chromosomally female mice transgenic for Sry. Nature, 351, 117-121.

LANFEAR, J. AND HOLLAND, P. W. H. 1991. The molecular evolution of ZFY-related genes in birds and mammals. J. Mol. Evol, 32, 310-315.

MAASWINKEL-MOOIJ, P. D., VAN ZWIETEN, P., MOLLERVANGER, P., VAN NOORT, E. AND BEVERSTOCK, G. 1992. A girl with 71, XXXXY karyotype. Clin. Genet., 41, 96-99.

McELREAVEY, K., VILAIN, E., ABBAS, N., HERSKOWITZ, I. AND FELLOUS, M. 1993. A regulatory cascade hypothesis for mammalian sex determination: SRY represses a negative regulator of male development. Proc. Natl. Acad. Sci. U.S.A., 90, 3368-3372.

MIGEON, B. R., SHAPIRO, L. J., IVORUM, R. A., MOHANDAS, T., AXELMAN, J. AND DABOVA, R. L. 1982. Differential expression of the steroid sulfatase locus on the active and inactive human X chromosome. Nature, 299, 838-839.

MITCHELL, M. J., WOODS, D. R., WILCOX, S. A., GRAVES, J. A. M. AND BISHOP, C. E. 1992. Marsupial Y chromosome encodes a homologue of the mouse Y-linked candidate spermatogenesis gene Ubely. Nature, 359, 528-531.

MIYATA, T., HAYASHIDA, H., KUMA, K., MITSUYASU, K. AND YASUNAGA, T. 1987. Male-driven molecular evolution: a model and 
nucleotide sequence analysis. Cold Spring Harb. Symp. Quant. Biol., 52, 863-867.

MOORE, T. AND HAIG, D, 1991. Genomic imprinting in mammalian development: a parental tug-of-war. Trends Genet., 7, 45-48.

OGATA, T. AND MATSUO, N. 1993. Sex chromosomes and stature: detection of the principal factor involved in the determination of adult height. Hum. Genet., 91, 551-562.

OGATA, T., HAWKINS, J. R., TAYLOR, A., MATSUO, N., HATA, J. AND GOODFELLOW, P. N. 1992. Sex reversal in a child with a 46, $\mathrm{X}, \mathrm{Yp}+$ karyotype: support for the existence of a gene(s), located in distal Xp, involved in testis formation. J. Med. Genet., 29, 226-230.

PAMILO, P. AND BIANCHI, N. o. 1993. Evolution of Zfx and Zfy genes: rates and interdependence between the genes. $\mathrm{Mol}$. Biol. Evol., 10, 271-281.

PETERS, L. L. AND BARKER, J. E. 1993. Novel inheritance of the murine severe combined anemia and thrombocytopenia (Scat) phenotype. Cell, 74, 135-142.

POMIANKOWSKI, A. AND HURST, L. D. 1993. Genomic conflicts underlying Haldane's rule. Genetics, 133, 425-432.

SALIDO, E. C., YEN, P. H., KOPRIVNIKOV, K., YU, L. C. AND SHAPIRO, L. J. 1992. The human enamel protein gene amelogenin is expressed from both the $\mathrm{X}$ and the $\mathrm{Y}$ chromosome. Am.J. Hum. Genet., 50, 303-316.

SCHIEBEL, K., WEISS, B., WOHRLE, D. AND RAPPOLD, G. 1993. A human pseudoautosomal gene ADP/ATP translocase, escapes $\mathrm{X}$-inactivation whereas a homolog on $\mathrm{Xq}$ is subject to X-inactivation. Nat. Genet., 3, 82-87.

SCHNEIDER-GÅDICKE, A., BEER-ROMERO, P., BROWN, L. G., NUSSBAUM, R. AND PAGE, D.C. 1989. $Z f x$ has a gene structure similar to $Z f y$, the putative human sex determinant, and escapes $\mathrm{X}$ inactivation. Cell, 57, 1247-1258.

SHIMMIN, L. C., CHANG, B. H.-J. AND LI, w.-H. 1993. Male driven evolution of DNA sequences. Nature, 362, 745-747.

SLIM, R., LEVILLIERS, J., LUDECKE, H. J., CLAUSSEN, U., NGUYEN, V. C., GOUGH, N. M., HORSTHEMKE, B. AND PETIT, C. 1993. A human pseudoautosomal gene encodes the ANT3 ADP ATP translocase and escpes X-inactivation. Genomics, 16, 26-33.

SMITH, M. J., GOODFELLow, P. J. AND GoODFELLow, P. N. 1993. The genomic organisation of the human pseudoautosomal gene MIC2 and the detection of a related locus. Hum. Mol. Genet., 2, 417-422.

SNEAD, M. L., LUO, W., HSU, D. D., MELROSE, R. J., LAU, E. C. AND STENMAN, G. 1992. Human ameloblastoma tumors express the amelogenin gene. Oral Surg. Oral Med. Oral Pathol., 74, 64-72.

TALMADGE, K., VAMVAKOPOULOS, N. C. AND FIDDES, J. C. 1984. Evolution of the genes for the $\beta$ subunits of human chorionic gonadotropin and luteinizing hormone. Nature 307, 37-40.

THORNHILL, A. R. AND BURGOYNE, P. S. 1993. A paternally imprinted $\mathrm{X}$ chromosome retards the development of the early mouse embryo. Development, 118, 171-174.

TRICOLI, J. V. AND BRACKEN, R. B. 1993. Zfy gene expression and retention in human prostate adenocarcinoma. Genes Chrom. Cancer, 6, 65-72.

TRICOLI, J. V., YAO, J. L., D'SOUZA, S. A. AND BRACKEN, R. B. 1993a. Detection of sex-region- $Y$ (Sry) transcripts in human prostate adenocarcinoma and benign prostatic hypertrophy. Genes Chrom. Cancer, 8, 28-33.

TRICOLI, J. V., YAO, J. L. AND D'SOUZA, S. A. 1993b. Evidence for the expression of the sex-region $\mathrm{Y}$ (SRY) gene in human renal cell carcinoma from males. Am. J. Hum. Genet., 53 (Suppl.), abstract no. 379.

TUCKER, P. K. AND LUNDRIGAN, B. L. 1993. Rapid evolution of the sex determining locus in Old World mice and rats. Nature, 364, 715-717.

VACQUIER, V. D. AND LEE, Y.-H. 1993 Abalone sperm lysin: unusual mode of evolution of a gamete recognition protein. Zygote, 1, 181-196.

WALKER, W. H., FITZPATRICK, S. L., BARRERA-SALDAÑA, H. A., RESÉNDEZ-PÉREZ, D. AND SAUNDERS, G. F. 1991. The human placental lactogen genes: structure, function, evolution, and transcriptional regulation. Endocr. Rev., 12, 316-328. WALLIS, M. 1993. Remarkably high rate of molecular evolution of ruminant placental lactogens. J. Mol. Evol., 37, 86-88.

WATSON, J. M., FROST, C., SPENCER, J. A. AND GRAVES, J. A. 1993. Sequences homologous to the human $\mathrm{X}$ - and Y-borne zinc finger protein gene $Z f x / y$ are autosomal in monotreme mammals. Genomics, 15, 317-322.

WHITFIELD, S. L., LOVELL-BADGE, R. AND GOODFELLOW, P. N. 1993. Rapid sequence evolution of the mammalian sex-determining gene $S R Y$. Nature, 364, 713-715.

WOLFE, K. H. AND SHARP, P. M. 1993. Mammalian gene evolution: nucleotide sequence divergence between mouse and rat. $J$. Mol. Evol., 37, 441-456.

YEN, P. H., ELLISON, J., SALIDO, E. C., MOHANDAS, T. AND SHAPIRO, L. 1992. Isolation of a new gene from the distal short arm of the human $\mathrm{X}$ chromosome that escapes $\mathrm{X}$-inactivation. Hum. Mol. Genet., 1, 47-52. 